\title{
Tunisia's Development Experience: A Success Story?
}

\section{Mina Baliamoune-Lutz*}

May 2009

\begin{abstract}
Tunisia's recent growth and development performance relative to countries in its region, and relative to countries at similar levels of development in other parts of the world, particularly in Sub-Saharan Africa, have been notable. An analysis of Tunisia's path to development reveals that the country's development strategy relied primarily on diversifying its production and trade and enhancing its human capital with emphasis on women's empowerment. Family planning programmes that have caused fertility to decline significantly are a hallmark of Tunisia's development strategy. This paper reviews Tunisia's experience, identifies the major challenges and threats to the viability of its development strategy, and pinpoints lessons for other countries.
\end{abstract}

Keywords: development, politics of co-optation, trade openness, fertility, human capital, women's empowerment, Tunisia

JEL classification: E6, F43, J13, O1

Copyright (C) UNU-WIDER 2009

*Department of Economics, University of North Florida, Jacksonville, email: mbaliamo@unf.edu

This study has been prepared within the UNU-WIDER project on Country Role Models for Development Success, directed by Augustin Kwasi Fosu.

UNU-WIDER gratefully acknowledges the financial contributions to the project by the Finnish Ministry for Foreign Affairs, and the financial contributions to the research programme by the governments of Denmark (Royal Ministry of Foreign Affairs), Finland (Finnish Ministry for Foreign Affairs), Sweden (Swedish International Development Cooperation Agency - Sida) and the United Kingdom (Department for International Development). 


\section{Acknowledgements}

This is a revised version of the paper presented at the UNU-WIDER Conference on 'Country Role Models for Development Success' held in Helsinki on 13-14 June 2008. I wish to thank Augustin Fosu and Ghassan Dibeh for very useful suggestions. I am also grateful to participants in session VIII (on Middle-East and North Africa) for their helpful comments.

\section{Acronyms}

EU European Union

FDI foreign direct investment

GATT General Agreement on Tariffs and Trade

MENA Middle East and North Africa

SSA Sub-Saharan Africa

UNECA United Nations Economic Commission for Africa

The World Institute for Development Economics Research (WIDER) was established by the United Nations University (UNU) as its first research and training centre and started work in Helsinki, Finland in 1985. The Institute undertakes applied research and policy analysis on structural changes affecting the developing and transitional economies, provides a forum for the advocacy of policies leading to robust, equitable and environmentally sustainable growth, and promotes capacity strengthening and training in the field of economic and social policy making. Work is carried out by staff researchers and visiting scholars in Helsinki and through networks of collaborating scholars and institutions around the world.

www.wider.unu.edu

publications@wider.unu.edu

UNU World Institute for Development Economics Research (UNU-WIDER)

Katajanokanlaituri 6 B, 00160 Helsinki, Finland

Typescript prepared by Liisa Roponen at UNU-WIDER

The views expressed in this publication are those of the author(s). Publication does not imply endorsement by the Institute or the United Nations University, nor by the programme/project sponsors, of any of the views expressed. 


\section{Introduction}

Morocco, Egypt, and Tunisia were all hailed as IMF success stories in the $1990 \mathrm{~s}, 1$ but only Tunisia continued its path to development at a sustained pace and succeeded in achieving remarkable progress in growth (with an average GDP growth rate exceeding 5 per cent in the 1990s) and human development (health and education), particularly for women. Tunisia achieved an international success mainly by enhancing its trade sector (exports) both in volume and in terms of its diversification, and achieved domestic success to a large extent by raising the level of its human capital (see Figure 1). Tunisia's development strategy involved significant political will, especially one that supported national education and women's rights. The country's recent performance in several social and economic dimensions relative to countries in its region, and relative to countries at similar levels of development in other parts of the world, particularly in Sub-Saharan Africa (SSA), has been remarkable.

In addition, Tunisia managed rather successfully the period of liberalization and reforms in the second half of the 1980s and early 1990s, and did not suffer from the fiscal deficits that often result from reducing or eliminating trade restrictions. UNECA (2004: 15) notes that:

most of the African countries that made the fastest progress in trade liberalization over the last ten years saw a significant decrease in revenues from international trade taxes. But in some, such as Ghana, Morocco, Senegal, and Tunisia, this did not translate into higher deficits.

Table 1 displays selected economic and social indicators in 2004 (unless noted otherwise) in Tunisia and in different groups of countries. It is shown that income per capita in Tunisia is higher than the average for middle-income countries, the MENA region, and the average in East Asia and the Pacific. Tunisia's openness to trade (trade as per cent of GDP) is higher than the average in any other region, and its ratio of manufacture exports as percent of GDP is 81 per cent, which is about the same as the average for the European Monetary Union and is greater than the average for all other regions. Tunisia has also shown significant progress in the social dimensions of development. The country outperforms the average for almost all other regions of developing and emerging countries in measures of life expectancy, age dependency, and fertility rates. In fact, fertility rates in 2004 are about one-third lower than the average for the MENA region and are less than one half the average rate observed in SSA (2.02 versus 5.31).

In summary, on the basis of several socioeconomic indicators Tunisia seems to perform better than the average middle-income country. However, in order to better assess Tunisia's accomplishments, we need to examine its progress over the last several years. Table A1 shows the composition of GDP in 1980 and 2000, in selected countries. We observe that Tunisia has managed to increase its per-capita income (PPP value) significantly from US\$3,763 to US\$5,730, an increase of 53 per cent in the course of two decades. Tunisia's progress in this area far exceeds that of the other two countries from the Maghreb region (Algeria and Morocco) but may not be considered impressive compared to countries such as Thailand, Malaysia, South Korea, and Mauritius. Income,

1 See Pfeifer (1999) for an interesting discussion of this point. 
however, is often an inadequate measure of a successful development strategy. The composition of income may tell us more about the directions the country has taken in the last two decades and help identify potential spillover effects on social and other development dimensions. The numbers displayed in Table A1 indicate that Tunisia had reduced the shares of agriculture (by 13 per cent) and industry (by 8 per cent) in its GDP, and increased the share of services by 8 per cent from 1980 to 2000 .

Tunisia's highly praised performance is not limited to economic achievements. Indeed, demographic and social indicators have registered important progress. Tunisia has the

Figure 1

Selected human development indicators

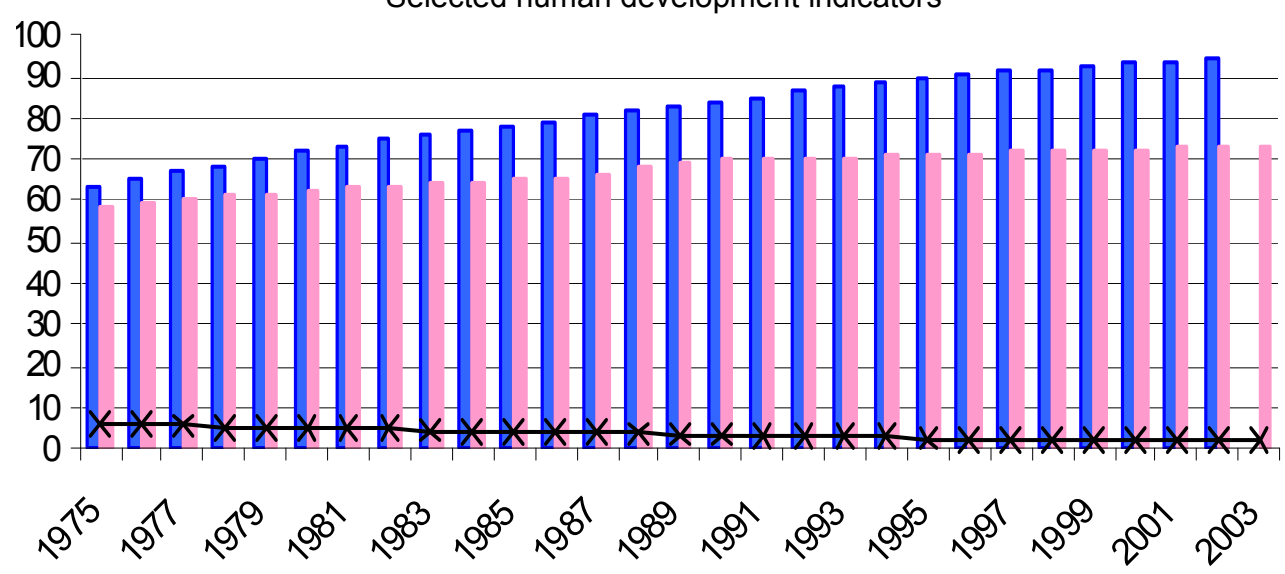

Source: World Bank (2006).

$\square$ Literacy rates $\quad$ Life expectancy $\quad x$ Fertility rates

Table 1

Selected economic and social indicators, 2004

\begin{tabular}{|c|c|c|c|c|c|c|c|c|c|}
\hline & 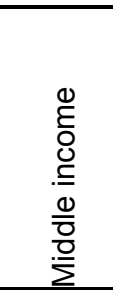 & 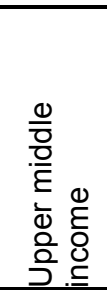 & 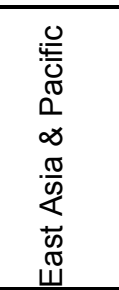 & 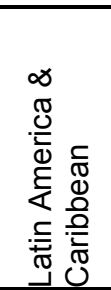 & 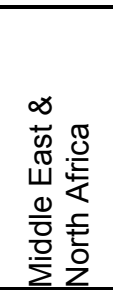 & $\begin{array}{l}\frac{\pi}{0} \\
\frac{0}{2} \\
\frac{1}{5} \\
0 \\
0\end{array}$ & 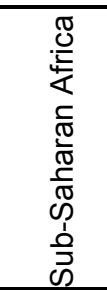 & $\sum_{\Psi}^{\supseteq}$ & $\begin{array}{l}\frac{\pi}{0} \\
\frac{0}{5} \\
\frac{5}{5}\end{array}$ \\
\hline Age dependency ratio & 0.49 & 0.51 & 0.46 & 0.57 & 0.63 & 0.63 & 0.89 & 0.5 & 0.49 \\
\hline $\begin{array}{l}\text { Credit to private sector } \\
\text { (\% of GDP) }\end{array}$ & 59.04 & 36.64 & 105.12 & 25.59 & 38.39 & 35.51 & 66.28 & 105.98 & 65.35 \\
\hline $\begin{array}{l}\text { Electrical power consumption } \\
\text { (per capita) } 2003\end{array}$ & 1708 & 3343 & 1184 & 1618 & 1213 & 394 & 513 & 6761 & 1118 \\
\hline Fertility rate, total & 2.13 & 1.94 & 2.01 & 2.45 & 3.04 & 3.11 & 5.31 & 1.5 & 2.02 \\
\hline $\begin{array}{l}\text { GDP per capita growth } \\
\text { (annual \%) }\end{array}$ & 6.3 & 6.14 & 8.13 & 4.49 & 3.71 & 6.22 & 2.86 & 1.62 & 5.05 \\
\hline $\begin{array}{l}\text { GDP per capita, PPP } \\
\text { (const. } 2000 \text { international \$) }\end{array}$ & 6176 & 9610 & 4923 & 7324 & 5334 & 2651 & 1803 & 25840 & 7163 \\
\hline $\begin{array}{l}\text { Labourforce, female } \\
\text { (\% of total) }\end{array}$ & 42.05 & 40.74 & 43.84 & 40.24 & 27.17 & 29.33 & 42.19 & 43.42 & 27.14 \\
\hline Life expectancy (yrs) & 70.04 & 69.21 & 70.28 & 72.18 & 69.35 & 63.41 & 46.22 & 79.38 & 73.3 \\
\hline $\begin{array}{l}\text { Manufacutures exports } \\
\text { (\% of exports) } 2003\end{array}$ & 64.18 & 61.23 & 80.22 & 56.13 & 20.39 & 79.07 & 31.37 & 81.76 & 81.5 \\
\hline Trade (\% of GDP) & 66.95 & 72.39 & 82.4 & 48.39 & 67.29 & 40.05 & 63.4 & 70.91 & 92.68 \\
\hline Rural population & 46.75 & 28.23 & 59.44 & 23.19 & 43.22 & 71.78 & 65.27 & 26.68 & 35.08 \\
\hline
\end{tabular}

Source: World Bank (2006). 
lowest fertility rate (around 1.8 per cent in 2005-07) in the Arab and Muslim world, and one of the lowest rates among middle-income countries. Infant mortality rates (per 1,000 live births) fell from 135 in 1970 to 20 in 2005, while in Algeria and Morocco, the rates in 2005 were 34 per cent and 36 per cent, respectively (UNDP 2008). Similarly, Tunisia has succeeded in lowering under-5 mortality rates from 201 in 1970 to 24 in 2005. In Algeria and Morocco these rates fell, respectively, from 220 to 39 and from 184 to 39, over the same period. Life expectancy in Tunisia is one of the highest in the MENA region and Africa, reaching an average of 73 years over the period 2000-05. In addition, women in Tunisia have experienced less gender inequality relative to women in other Arab countries, thanks in a large part to family planning programmes and pro-women laws that have been enforced throughout the three-decade tenure of President Bourguiba, and seem to have continued since the end of his presidency in 1987.

The main purpose of this paper is to review Tunisia's development strategy, outline the reasons for its success, and assess the viability of this strategy in the future in the face of some major challenges, particularly high unemployment. The paper also tries to pinpoint the lessons that can be learned or replicated by other countries. The remainder of the paper is organized as follows. Section 2 provides an overview of Tunisia's development strategy highlighting in particular the role of diversification and human development. Section 3 discusses the main reasons for the success of Tunisia's development strategy. Section 4 comments on the challenges that need to be addressed in order for Tunisia's development strategy to continue its success. Section 5 outlines the main lessons for other countries. Concluding comments are presented in the final section.

\section{Tunisia's development strategy and how it was pursued}

In general, Tunisia's development strategy focused on three main areas: (i) diversification of its economy (and exports), (ii) investing in human capital, and (iii) empowering women. These three areas are interlinked and have had important spillover effects on each other, as well as on other economic and social dimensions of the Tunisian society.

Tunisian timeseries data for the period 1970-2003 indicate that there are significant correlations between human development measures, institutional quality, trade indicators, and income. The correlation coefficients displayed in Table 2 indicate strong (high values and highly significant) positive correlation between income on the one hand, and the indicators of human capital (literacy, life expectancy, and the share of women in the labourforce), institutional quality (ICRG index), and trade and trade diversification (trade, the share of manufactures in exports, and the entropy index) ${ }^{2}$ on

2 The entropy index (used here as a measure of export diversification) is given by the following formula.

$$
\text { Entropy }=\sum_{i=1}^{N} P_{i} \log _{2}\left(1 / p_{i}\right)
$$

$N$ is the total number of export commodities in the export portfolio and $P i$ represents the actual share of the ith commodity in total exports. The maximum value of the entropy index occurs when all the $P i$ are equal. This implies maximum diversification as all commodities in the export portfolio have identical share. Thus, higher values of the Entropy index imply higher diversification (Ben Hammouda et al. 2006). 
Table 2

Correlations

\begin{tabular}{|c|c|c|c|c|c|c|c|c|c|c|c|}
\hline & Income & Entropy & Trade & FDI & Literacy & Fertility & Credit & Growth & ICRG & $\begin{array}{l}\text { Manuf- } \\
\text { exports }\end{array}$ & $\begin{array}{c}\text { Female } \\
\text { labour- } \\
\text { force (share) }\end{array}$ \\
\hline Entropy & $\begin{array}{l}0.711 \\
0.000\end{array}$ & & & & & & & & & & \\
\hline Trade & $\begin{array}{l}0.737 \\
0.000\end{array}$ & $\begin{array}{l}0.484 \\
0.016\end{array}$ & & & & & & & & & \\
\hline FDI & $\begin{array}{l}0.339 \\
0.076\end{array}$ & $\begin{array}{r}-0.129 \\
0.546\end{array}$ & $\begin{array}{l}0.670 \\
0.000\end{array}$ & & & & & & & & \\
\hline Literacy & $\begin{array}{l}0.977 \\
0.000\end{array}$ & $\begin{array}{l}0.861 \\
0.000\end{array}$ & $\begin{array}{l}0.894 \\
0.000\end{array}$ & $\begin{array}{l}0.594 \\
0.000\end{array}$ & & & & & & & \\
\hline Fertility & $\begin{array}{r}-0.960 \\
0.000\end{array}$ & $\begin{array}{l}0.892 \\
0.000\end{array}$ & $\begin{array}{r}-0.898 \\
0.000\end{array}$ & $\begin{array}{r}-0.596 \\
0.000\end{array}$ & $\begin{array}{r}-0.996 \\
0.000\end{array}$ & & & & & & \\
\hline Credit & $\begin{array}{l}0.292 \\
0.131\end{array}$ & $\begin{array}{r}-0.134 \\
0.532\end{array}$ & $\begin{array}{l}0.093 \\
0.550\end{array}$ & $\begin{array}{l}0.518 \\
0.000\end{array}$ & $\begin{array}{l}0.185 \\
0.234\end{array}$ & $\begin{array}{r}-0.201 \\
0.189\end{array}$ & & & & & \\
\hline Growth & $\begin{array}{l}0.013 \\
0.947\end{array}$ & $\begin{array}{l}0.069 \\
0.746\end{array}$ & $\begin{array}{l}0.051 \\
0.743\end{array}$ & $\begin{array}{l}0.039 \\
0.797\end{array}$ & $\begin{array}{l}0.043 \\
0.780\end{array}$ & $\begin{array}{r}-0.093 \\
0.546\end{array}$ & $\begin{array}{l}0.044 \\
0.773\end{array}$ & & & & \\
\hline ICRG & $\begin{array}{l}0.898 \\
0.000\end{array}$ & $\begin{array}{l}0.824 \\
0.000\end{array}$ & $\begin{array}{l}0.693 \\
0.000\end{array}$ & $\begin{array}{l}0.432 \\
0.003\end{array}$ & $\begin{array}{l}0.899 \\
0.000\end{array}$ & $\begin{array}{r}-0.896 \\
0.000\end{array}$ & $\begin{array}{l}0.153 \\
0.327\end{array}$ & $\begin{array}{l}0.098 \\
0.532\end{array}$ & & & \\
\hline Manuf-exports & $\begin{array}{l}0.938 \\
0.000\end{array}$ & $\begin{array}{l}0.858 \\
0.000\end{array}$ & $\begin{array}{l}0.505 \\
0.000\end{array}$ & $\begin{array}{l}0.309 \\
0.041\end{array}$ & $\begin{array}{l}0.695 \\
0.000\end{array}$ & $\begin{array}{r}-0.682 \\
0.000\end{array}$ & $\begin{array}{l}0.198 \\
0.197\end{array}$ & $\begin{array}{l}0.195 \\
0.204\end{array}$ & $\begin{array}{l}0.691 \\
0.000\end{array}$ & & \\
\hline Female labourforce & $\begin{array}{l}0.980 \\
0.000\end{array}$ & $\begin{array}{l}0.387 \\
0.061\end{array}$ & $\begin{array}{l}0.946 \\
0.000\end{array}$ & $\begin{array}{l}0.683 \\
0.000\end{array}$ & $\begin{array}{l}0.923 \\
0.000\end{array}$ & $\begin{array}{r}-0.904 \\
0.000\end{array}$ & $\begin{array}{l}0.242 \\
0.113\end{array}$ & $\begin{array}{l}0.090 \\
0.560\end{array}$ & $\begin{array}{l}0.715 \\
0.000\end{array}$ & $\begin{array}{l}0.521 \\
0.000\end{array}$ & \\
\hline Life & $\begin{array}{l}0.916 \\
0.000\end{array}$ & $\begin{array}{l}0.946 \\
0.000\end{array}$ & $\begin{array}{l}0.949 \\
0.000\end{array}$ & $\begin{array}{l}0.620 \\
0.000\end{array}$ & $\begin{array}{l}0.972 \\
0.000\end{array}$ & $\begin{array}{r}-0.982 \\
0.000\end{array}$ & $\begin{array}{l}0.175 \\
0.253\end{array}$ & $\begin{array}{l}0.098 \\
0.524\end{array}$ & $\begin{array}{l}0.819 \\
0.000\end{array}$ & $\begin{array}{l}0.636 \\
0.000\end{array}$ & $\begin{array}{l}0.947 \\
0.000\end{array}$ \\
\hline
\end{tabular}

Notes: Most data are for the period 1970-2003. Credit: domestic credit to private sector (\% of GDP); FDI: foreign direct investment, net inflows ( per cent of gross capital formation); fertility: fertility rate, total (births per woman); literacy: literacy rate, adult total (\% of people aged 15 and above)

Income (log): log of GDP per capita, PPP (constant 1995 international \$); ICRG: International Country Risk Guide, composite risk rating (0=highest risk to $100=$ lowest); female labourforce: Labourforce, female (\% of total labourforce); life: Life expectancy at birth, total (years); manuf-exports: Manufactures exports (\% of merchandise exports); trade: Exports plus imports (\% of GDP).

Source: World Bank (2006). 
the other. As expected, there is a strong negative association between income and fertility rates. Fertility rates also have high correlations (with expected signs) with life expectancy, literacy, the share of women in the labourforce, trade and trade diversification, and institutional quality.

Surprisingly, credit to the private sector (the variable credit) does not have any significant association except with foreign direct investment (FDI). In addition, growth in GDP per capita (growth) does not show any significant correlation with the other variables, suggesting that the association between growth and the other variable may be better detected over a longer period of time, such as 5-year or 10-year averages; or that there is no significant contemporaneous correlation between growth and the other variables.

\subsection{Diversification}

\subsubsection{Production diversification}

Ghali and Mohnen (2004) identify three phases in Tunisia's development. The first phase started in 1961 and ended in 1970, and was characterized by 'high growth rates driven by substantial public investments in basic infrastructure, human resource development, and agricultural expansion'. This phase ended with a 'macroeconomic crisis' resulting from several factors, including high public debt and current account deficits, and poor performance of the agricultural sector due to frequent drought. The next phase began in 1971 and ended in 1986 and was characterized by what the authors call 'a mixed economy', where the private initiative was encouraged and the private sector, particularly in manufacturing, began to develop. Export promotion was encouraged through tax incentives and tariff exemption for the import of machinery and equipments. However, this phase was also characterized by significant government control of the economy, including maintaining price and interest rate controls, and a preference for expansionary fiscal and monetary policy. As a result, serious macroeconomic imbalances developed in the first half of the 1980s and Tunisia agreed to an IMF structural adjustment programme in 1986.3 As noted in Ghali and Mohnen, structural adjustment efforts characterized the period from 1987 onwards (phase three). Phase three witnessed important trade and financial sector liberalization initiatives, the accession to the General Agreement on Tariffs and Trade (GATT) membership, and the free trade agreement with the European Union (EU) in 1995.

Tunisia's success is, to a large extent, due to its ability to achieve good economic performance since the mid-1980s. In particular, Tunisia has succeeded in deepening its diversification process in a period of structural adjustments. Given that the rapid liberalization and reforms that usually accompany such adjustment programmes can limit a country's ability to diversify its economy (see UNECA 2007), Tunisia's deepened economic diversification is a significant achievement.

The diversification process in Tunisia, as in many other African countries, began shortly after its independence from France (in 1956) and picked up pace since the mid-1980s.

3 For more on the reforms in Tunisia and other Maghreb countries, see Jbili, Enders and Treichel (1997), Ravallion and Lokshin (2004), World Bank (2004), and Addison and Baliamoune-Lutz (2006). 
In this context, UNECA 2007 Economic Report on Africa (2007: 9).states the following:

Two distinct periods stand out in Africa's development strategy. The period spanning the 1960s and the 1970s was characterized by policies aimed at strengthening economic autonomy. It is during this period that diversification oriented policies were aggressively pursued in most countries. A major shift in economic policies in Africa was occasioned by the economic crises of the early 1980s. Most of the post independence economic policies geared to long-term development were replaced by macroeconomic stabilization policies focusing on short-term goals.

Tunisia has deviated from this general trend since the mid-1980s. Indeed, UNECA (2007) places Tunisia among the group of countries that have 'deepened the diversification process' (see Table A2). However, in relatively small countries diversification of the economy may need to translate into diversification of exports in order to generate significant gains (through, for example, economies of scale and access to more advanced technologies). As shown in Figure 2, there was a significant rise in manufacturing exports, and a sharp decline in food and agricultural exports.

Tunisia faced two major constraints in the early stages of its development strategy. In general, in order to develop a significant manufacturing sector, an economy needs welldeveloped power sources (energy) and raw materials, and large markets; both of which were rather in limited supply in Tunisia. For many years, Tunisia's manufacturing (and exports) focused mainly on textile and leather, and food products. Although, the textile and clothing sector remains significant, in the late 1980s and early 1990s Tunisia began to significantly enhance the diversification of its production and exports by adding, for example, production and export of chemicals and mechanical, electric, and electronic equipment. These efforts were supported by significant FDI inflows, which in turn were responsive to the new Tunisian investment codes of the 1980s. During the same period of time important liberalization and privatization programmes began to be implemented.

Figure 2

Shares of food, manufacturing, agriculture and raw materials in exports

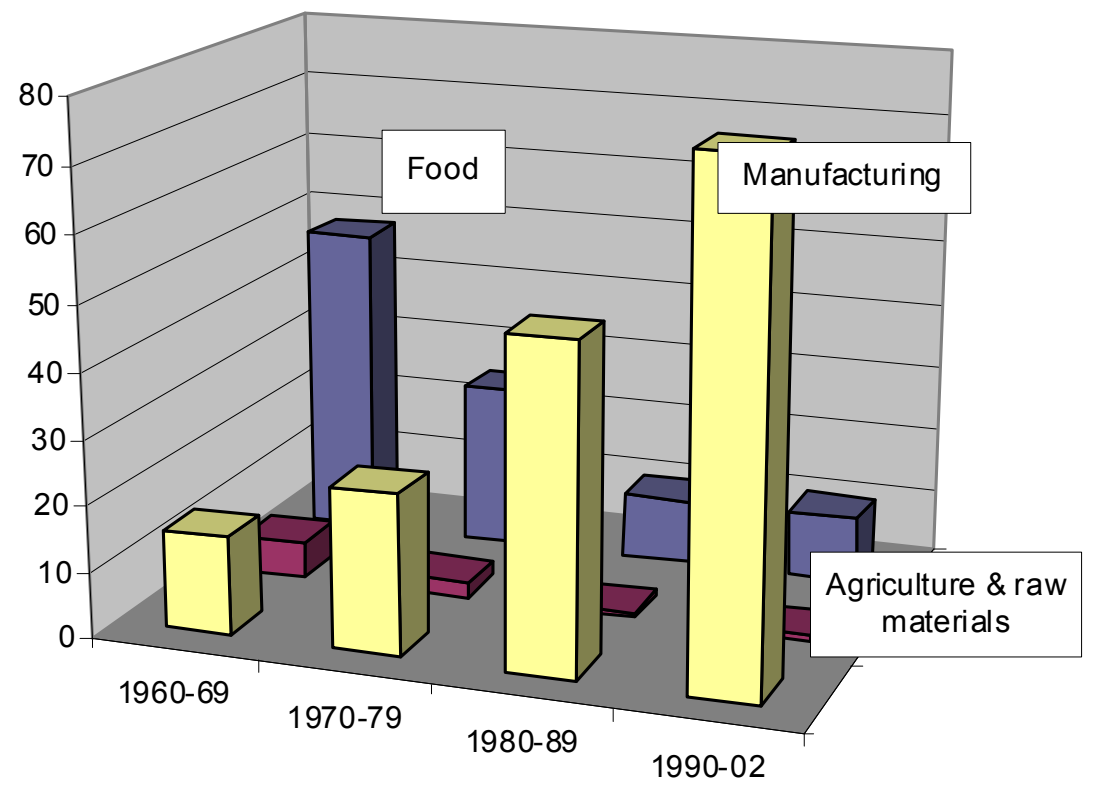

Source: World Bank (2006). 


\subsubsection{Trade and export diversification}

The trade ratio in Tunisia has been consistently higher than that of other North African countries and there was significant growth in exports since the mid-1980s (Table A3). Because this can sometimes be explained by the relatively small size of the country - as small countries tend to have a higher trade sector - it would be more useful to examine the dynamics of Tunisia's trade sector. As indicated in Table A3, Tunisia's share of manufactures in merchandise exports has significantly increased (from about 36 per cent in 1980 to 77 per cent in 2000). 4 The share of ores and metal has declined from 3.6 per cent in 1980 to 1.5 per cent in 2000 . The share of import duties in Tunisia's tax revenues fell from about 31 per cent in 1980 to 12.5 per cent in 2000, reflecting an overall downward trend in import duties. Since the mid-1980s, Tunisia has been one of two countries (Morocco is the other one) in North Africa with the most consistent positive average growth rates in merchandise exports (Table 3 ).

Tunisia has a relatively well-diversified economy and this diversification is also apparent in the composition of its exports in recent years. The entropy index (an indicator of diversification) increased by about 60 per cent, from 1.02 in 1980 to 1.62 in 2003 (Table 4). It is worth noting that the trend in trade (export) volume has closely matched the trend in export diversification (Table 4). Figure 3 portrays the behaviour of the trade ratio, export ratio, and the diversification indicator (1980-2003). We observe that since the mid-1980s these variables seem to have consistent co-movements.

Table 3

Growth of merchandise exports in North Africa, 1980-2003 (\%)

\begin{tabular}{lccccc}
\hline & $1980-85$ & $1985-90$ & $1990-95$ & $1995-00$ & $2001-03$ \\
\hline Algeria & -2.2 & 1.7 & -6.3 & 10.4 & 2.3 \\
Egypt & 2.7 & 12.8 & -6.4 & 3.9 & 5.3 \\
Morocco & -2.6 & 14.0 & 8.7 & 0.8 & 9.4 \\
Tunisia & -6.4 & 16.0 & 8.4 & 1.6 & 11.3 \\
\hline
\end{tabular}

Source: UNCTAD (2004).

Table 4

Trade and diversification

\begin{tabular}{lccc}
\hline Period & $\begin{array}{c}\text { Entropy diversification } \\
\text { index }\end{array}$ & $\begin{array}{c}\text { Trade } \\
\text { (\% of GDP) }\end{array}$ & $\begin{array}{c}\text { Exports } \\
(\% \text { of GDP })\end{array}$ \\
\hline $1980-84$ & 1.09 & 83.15 & 37.17 \\
$1985-89$ & 1.37 & 76.81 & 36.70 \\
$1990-94$ & 1.51 & 89.40 & 41.75 \\
$1995-99$ & 1.49 & 89.19 & 43.23 \\
$2000-03$ & 1.57 & 94.00 & 44.98 \\
\hline
\end{tabular}

Source: World Bank (2006); Ben Hammouda et al. (2006).

4 See Fosu (2002) for an insightful discussion of the importance of exporting manufactured goods. 


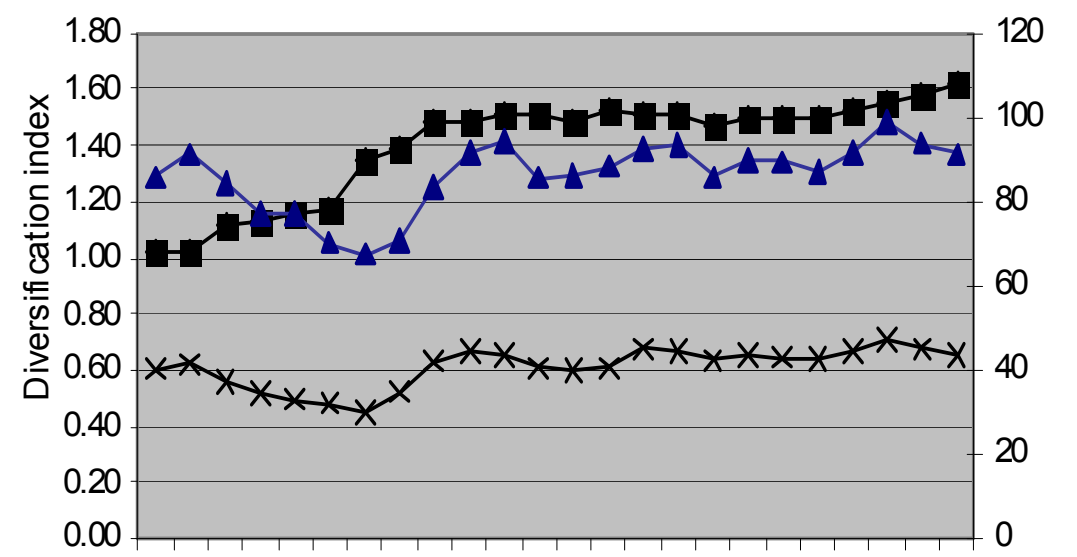

Source: Data on the index of entropy are from Ben Hammouda et al. (2006). Data on the export ratio and openness index from World Bank (2006).

Tunisia's experience with diversification is highlighted in the UNECA Economic Report (of 2004: 8), which notes the following.

Over the last two decades Africa has made gradual but insufficient progress in export diversification... A few African countries, such as Kenya and Uganda, have moved into non-traditional exports, typically, vegetables, fruits, and flowers. Even more encouraging are the few countries that have successfully promoted manufacturing exports, such as Mauritius and Tunisia. These experiences can provide lessons for other African countries.

\subsection{Human development}

Tunisia tackled two issues better than most Arab and Muslim countries, and began to do so shortly after its independence from France. First, to reduce gender inequities it instituted laws that were less unfavourable to women, including laws pertaining to marriage and divorce, and the right to vote and stand for election. The first woman was elected to parliament in 1959 (in Morocco, for example, this did not happen until 1993!). Second, to improve human development Tunisia placed more emphasis on education. Four decades later, Tunisia outperformed all North African countries (see Baliamoune-Lutz 2006) and many of the remaining MENA and African countries in women's health, fertility rates (which are now comparable to fertility rates in some developed countries), and literacy rates, especially female literacy. Perhaps it is this early start in focusing on human development (health and education) and on the important role of women in society that provided Tunisia with good initial conditions for its successful development strategy. It is worth stressing that Habib Bourguiba, the first president of independent Tunisia (ruled from 1957 to 1987 and is viewed by many as the father of modern Tunisia) was quite supportive of women's rights. Bourguiba 
made polygamy illegal and raised the minimum age at which girls can get married to 17 years of age. Thus, a significant political will was behind the policies of family planning, generalized access to education, and women's rights in Tunisia. Bourguiba's policies had a significant impact on the behaviour of fertility rates and women's education and participation in the labourforce.

Tunisia had much more success than other Maghreb countries in reducing poverty rates in both urban and rural areas. As Table 4 shows, although Tunisia had higher poverty rates than Algeria in the 1980s, it achieved significantly lower rates in the mid-1990s. In 1992, Tunisia created a programme known as the National Solidarity Fund with the aim to use it as a vehicle through which private and public donations are channelled to development projects. This was one of the initiatives (several others were created since then) of the 1990s aimed at reducing the adverse effects of liberalization and reform programmes.

Table 4

Rural and urban poverty

\begin{tabular}{lccrrr}
\hline & \multicolumn{2}{c}{$1984-85$} & & \multicolumn{2}{c}{$1998-99$} \\
\cline { 2 - 3 } \cline { 5 - 6 } & Urban & Rural & & Urban & Rural \\
\hline Morocco & 17.3 & 32.6 & & 12.0 & 27.2 \\
Tunisia & 12.0 & 29.2 & & $3.6^{\mathrm{a}}$ & $13.9^{\mathrm{a}}$ \\
Algeria & $7.3^{\mathrm{b}}$ & $16.6^{\mathrm{b}}$ & & 14.7 & 30.3 \\
\hline Notes & ${ }^{\mathrm{a}}{ }_{\text {1995; }}{ }^{\mathrm{b}}$ 1988. & & & \\
Source: & Adapted from Baliamoune-Lutz (2006).
\end{tabular}

\subsubsection{Education}

In Tunisia, schooling is obligatory between the age of 6 and 16, and is free to all schoolaged children. Tunisia has always viewed public education as a national priority. It seems that this strategy is currently paying off and contributing significantly to Tunisia's development (see discussion in the next section). During the last 15 years, Tunisia more than doubled the ratio of its spending on public education, increasing it from 6 per cent of its GDP (7.3 per cent of total government expenditure) in 1991 to 14.2 per cent of its GDP (20.8 per cent of total government expenditure) in 2002-05. Moreover, an important reform took place in July 1989 when the government introduced free obligatory education until the age of 16 and increased the basic education cycle to nine years. These reforms were accompanied by several actions to enhance teacher quality such as hiring more teachers with higher degrees and enhancing school computerization. Ghali and Mohnen (2004: 2) note that 'with these measures, dropout rates have decreased steadily. Achievements in education have not only helped reduce poverty, but have also created an increasingly educated and productive workforce'.

Adult literacy rates increased from 27.4 per cent in 1970 to over 73 per cent in 2002 , and youth literacy rates increased from 52 per cent to over 94 per cent over the same period. More impressive is the change in female literacy. In 1970, female literacy was about 15 per cent while male literacy was 41 per cent. In 2002, these rates were about 63 per cent and 83 per cent, respectively. The gap in youth literacy in 2002 is much smaller (female and male literacy rates are 91 per cent and 98 per cent, respectively). Similarly, secondary school enrolment (per cent gross) increased from about 23 per cent in 1970 to 78 per cent in 2002. Since the late 1990s female secondary school enrolments 
have been greater than male enrolment rates (in 2002, they were 80 per cent and 77 per cent, respectively). In 2002, enrolments in higher education (tertiary) were about 23 per cent ( 25 per cent for women and 20 per cent for men), which is quite high relative to Tunisia's region. In 2005, tertiary enrolments rate for Tunisian women was 35 per cent (40 per cent higher than that of their male counterparts), which is higher than the rates registered in Hong Kong or Mexico, for example. In contrast, Morocco's female tertiary enrolment rate was 10 per cent (about 15 per cent lower than the rate for men) (UNDP 2006).

\subsubsection{Fertility and other health indicators}

Tunisians have a relatively high life expectancy. In 2005, life expectancy in Tunisia was 73.5, which is six years higher than the average for Arab states, and higher than the average in Latin America, middle-income countries, and East-Asia and the Pacific. Mortality rates in Tunisia are among the lowest in the region. In addition, Tunisia has one of the lowest under-five mortality rates in Africa and the Arab region. Under-five mortality rates (per 1,000) in Tunisia fell from 254 in 1960 to 26 in 2002, while Morocco, for example, had less success; reducing the rate from 211 to 43, over the same period of time.

Tunisia's success in controlling population growth has been quite remarkable. Bechri and Naccache (2003: 17) maintain that 'population control allowed Tunisia to enter a "virtuous circle" with population control enhancing socio-economic development, and socio-economic development, in turn, enhancing population control. This "Tunisian exception" will later on explain the country's status as a top performer in terms of GDP per capita growth, in the region'.

The topic of family planning and fertility rates in Tunisia has been extensively studied since the 1960s due, to a large extent, to the country's good quality statistics on fertility and family planning. Povey and Brown (1968: 620) report the following.

Since independence in 1956, a number of legislative steps have been taken which tend to decrease population growth. Women were emancipated and given the vote. The minimum legal age of marriage was made 17 for women and 20 for men. Other actions deliberately reversed the pro-natalist policy established by the French. The law prohibiting the importation and sale of contraceptives was revoked. Welfare support was limited to the first four children. In 1965, abortion was made legal for women with five or more living children. Discussions between the Government of Tunisia and the Ford Foundation on family planning began in $1962 \ldots$ Tunisia thus became the first country on the continent of Africa to institute a national family planning programme.

Similarly, Lapham (1970) states that one third of the decline in birth rates in Tunisia in 1967 and 1968 could be attributed to the national family planning programme. Rising the minimum legal age and empowering women in Tunisia seem to have contributed to what Fargues (1989) calls 'marriage transition'.5 The author argues that this transition is associated with two important changes: an educational transition (women's education increases), and increased female participation in the labourforce. Both of these changes

5 See Chamari (1991) for a discussion (in French) of the effects of the legal aspects of women's status in Tunisia and their contribution to the country's development strategy. 
have taken place in Tunisia. Indeed, Fargues (1989) notes that 'Tunisia is a striking example of what can be termed a real "educational transition", .

\subsection{Linkages between trade, human capital, and income}

Ghali and Mohnen (2004: 2) contend that:

while growth and poverty reduction in Tunisia were driven largely by the economic reforms of the late 1980s, they were augmented and reinforced by the pursuit of economic and social policies that focused on improving individual and collective welfare, especially in education, health, and social assistance.

Indeed, it seems that Tunisia's social policy played an important role in the success of its economic reform by enabling the diversification of its economy and exports, upgrading of the labourforce quality and enhancing human capital (education, health, and female participation), and facilitating collective action. Human capital in particular contributed significantly to strengthening the set of initial conditions for the implementation of Tunisia's development strategy and the success of the manufacturing sector and the diversification process. Another contributor to the good initial conditions is the country's geographical location. Tunisia is in the southern Mediterranean region, with a climate that is generally favourable to tourism and agriculture. Its proximity to Europe has been an important trade (and FDI) enabler with the EU countries, Italy and France, in particular. In 2005, the share of exports to these two countries was about 60 per cent of Tunisia's total exports.

Ghali and Mohnen (2004) note that Tunisia's successful experience can be attributed to (i) successful implementation of economic reform and stabilization programmes (since the mid 1980s); (ii) the focus on social policy (education, social security, health, and helping the poor); (iii) the decline in population growth; and (iv) continuing investment in basic infrastructure. The spillover effects and the linkages between human capital, social policy, and economic policy seem indeed to be crucial to the success of Tunisia's development experience.

In a recent study, Baliamoune-Lutz (2008) examines long-run relationships and shortrun dynamics in the relationship between variables related to trade, income, and human development in Tunisia and finds that income per capita, diversification indicators, the share of women in the labourforce, adult literacy, and fertility rates are cointegrated, suggesting stable long-run relationships among these variables. The same study tests for pairwise Granger causality6 between several variables but does not find evidence of pairwise Granger causality between income, trade openness, and the share of manufactures in exports. On the other hand, the author finds that the indicator of diversification (entropy index) Granger causes openness to trade and FDI. These results seem to be consistent with Tunisia's story of the important impact of diversification. In addition, Baliamoune-Lutz (2008) finds that the share of women in the labourforce Granger causes income, openness to trade, and manufacturing exports; female literacy causes the share of women in the labourforce; while fertility rates cause openness to trade and the female labourforce.

6 Granger causality tests allow us to investigate whether past values of a variable can be useful for anticipating the future behaviour of another variable. 


\section{Reasons for the success of Tunisia's development strategy}

\subsection{Political economy: Reforms and interest groups 7}

In the mid-1950s there were several major (organized) interest groups in Tunisia, including the ruling party (Neo-Destour) elite, producers' associations and labour unions. From the start, the Bourguiba regime used neutralization and co-optation of major interest groups, which helped avoid confrontation and facilitate coordination. As pointed out by Bechri and Naccache (2003), the leadership of producers' association was neutralized, and the only interest groups that could significantly influence government policy were the ruling party elite and the national labour union UGTT, which had infiltrated (co-optation) the Neo-Destour party. The authors also point out that Tunisia ended up implementing the UGTT policies. This was an important factor in reducing (or eliminating) conflict.

The secular and modernist leadership in independent Tunisia gave the country an early start on some important reforms. Social modernization played a crucial role in Tunisia's development. In the late 1950s, Tunisia implemented the most progressive reforms of female status and women's rights in the Arab and Islamic world (perhaps with the exception of Turkey) and began focusing on female education, reproductive health, and population control. In the early 1960s, Tunisia created a family planning agency (Office National de Planning Familial) and limited social security benefits to a maximum of three children per family, which eliminated an important incentive to have a large family. These policies faced sharp criticism from most countries in the Islamic and Arab world. The policies of neutralization and co-optation of other interest groups allowed the leadership of the ruling party to implement these social policies early on and without major internal political or social confrontation.

On the other hand, economic policy has vacillated between several tendencies, including socialism and central planning in the 1960s, a two-track economic system in the 1970s, and economic populism during the first half of the 1980s. In 1972 (under the two-track strategy), Tunisia adopted the off-shore companies law, which granted export firms duty-free import of equipment and other inputs, and significant tax exemptions. The government also enhanced credit for small and medium enterprises, and created a government agency for promoting industry and a centre for export promotion in order to help exporters access foreign markets. The two-track strategy pursued in the 1970s seems to be relevant to policy developments of the late 1980s and 1990s. Bechri and Naccache (2003: 24) note the following.

Export-oriented industries are a priori in a good position to influence policy since they help achieve an important government objective. A particular success in this respect was scored by the 'mechanicals and electricals' sector. This activity started as an import-substitution aimed at absorbing local demand. But, the establishment of foreign companies including some multinationals' subsidiaries demonstrated to Tunisian business the existence of opportunities in exports for

7 Bechri and Naccache (2003) argue that the theory of collective action cannot explain why inefficiencies prevail and does not explain the timing of reforms or why a severe crisis leads to reforms in some countries but not in others. In the case of Tunisia, the authors focus on three institutional dimensions: representation, coordination, and commitment. 
products like autoparts, cables, and batteries. As a result, the sector shifted gradually from import substitution to exportables.

The most significant economic reforms occurred in the latter part of the 1980s. Tunisia experienced a severe balance-of-payment crisis in 1986 and had to adopt an IMF structural adjustment and stabilization programme, including strong devaluation of the Tunisian dinar and restrictive monetary and fiscal policies. A change in the political leadership took place three months after Tunisia started the structural adjustment programme but the politics of co-optation have continued, which again helped to avoid confrontation and facilitate coordination.

An important contributing factor to the success of the economic reforms and export orientation is the 'cooperation' of important interest groups. This seems to be reflected in the role played by exporters, especially in the textiles and clothing, and mechanical and electrical sectors. Indeed, Bechri and Naccache (2003) argue that 'the three decades old export-oriented strategy in Tunisia ended up creating a new constituency, which has a stake in export'. This also helped support Tunisia's signing of the free trade agreement with the EU.

\subsection{Political stability}

Since independence Tunisia has not, in general, experienced any significant political instability. In November 1987, a 'peaceful' coup was staged against Bourguiba who was declared to be unfit for the presidency and the newly-appointed prime minister, Zine El Abidine Ben Ali, became president and was re-elected for successive terms since November 1987. In addition, Tunisia's military spending as a percentage of its government budget is much smaller than the world average (and the average for the MENA region) and seems to indicate a smaller role of the military in Tunisia relative to the military sector in Egypt, Algeria and Morocco, for example.

The impact of political stability on exports has been documented by Fosu (2003). The author studies the effect of political instability on export performance in 30 African countries and shows that this effect is negative. Thus, the Tunisian case confirms Fosu's finding. More recently, Tunisia's success has also been helped by improved institutional quality (UNECA 2007). Several empirical studies (for example, Dollar and Kraay 2003; Addison and Baliamoune-Lutz 2006) show that institutions can have a significant effect on economic policy reforms.

\section{Does Tunisia's development strategy remain viable for the future?}

Tunisia currently faces several challenges that may threaten the viability of its development strategy in the future. First, unemployment, particularly among educated Tunisians remains high (around 15 per cent on average in recent years). In 2003, the official unemployment rate was 14.3 per cent, and 47 per cent of the unemployed had completed secondary (37.4 per cent) or tertiary (10 per cent) education. 8 Tunisia's 1995

8 See Ghali and Mohnen (2004) for a discussion of the factors that may have contributed to high unemployment rates in Tunisia. 
agreement with the EU will create a free trade zone between EU countries and Tunisia in 2010 , and this may exacerbate the unemployment situation.

Second, there is still high regional inequality, particularly between rural and urban areas. Poverty is much higher in rural areas (King 1999). Thus, Tunisia may need to significantly increase spending on social programmes, health, and education in order to reduce poverty in rural areas. While this may be costly, the alternative (status quo) could have even more disastrous consequences. Tunisia already has the highest ratio of urban population among the four largest North African countries (Algeria, Egypt, and Morocco being the other three) with more than two-thirds of its population living in urban areas (in 2005). A continuous high influx from rural areas may increase the fragility of the infrastructure and social structure of the cities.

Third, Tunisia's financial sector has been liberalized, as part of the liberalization and reform programmes of the late 1980s and early 1990s but it has failed to mobilize significant domestic savings. State-owned (public) banks dominate in terms of size (around 50 per cent of the banking sector assets) and tend to have high inefficiency (Cook, Hababou and Liang 2005). Credit to the private sector is not high enough, so that small and medium private businesses often are unable to have access to bank loans. Having access to credit is especially important in the context of production and export diversification.

Finally, the current president (Ben Ali) is 72 years old and, according to Tunisia's constitution, he cannot run for another term once he reaches 75 , which implies that he will still be able to run for a fifth term in 2009 . The country has had only two presidents since independence over half a century ago. This raises the question of whether Tunisia would be able to continue the kind of political stability that had an important impact on its development strategy after Ben Ali's departure.

\section{$5 \quad$ Lessons for other countries}

There are at least three lessons to be learned from the Tunisian experience. The first lesson and perhaps easiest to replicate is Tunisia's success in reducing fertility rates and enforcing family planning, which is particularly relevant for countries that have high population growth such as Arab and African countries. Lower fertility rates alone will not necessarily lead to higher growth and development. As argued in this paper, Tunisia invested significantly in education and health. This in turn, enhanced productivity and female participation in the labourforce, resulting in better and greater human capital. The development effects from reduced fertility can be quite significant. Yet, political factors and the associated institutional arrangements can be crucial to the behaviour and effects of fertility. Indeed, Feng, Kugler and Zak (2000) show that political factors have a significant effect on fertility decisions and that 'a one-time disturbance compounds across generations, impacting a country's entire development trajectory'.

The second lesson is that social policy reforms can significantly aid economic reforms. As noted earlier, Tunisia's social policy was quite progressive and contributed significantly to enhancing initial conditions, particularly with regard to the welfare and role of women. 
The third lesson concerns the role of political stability. It is important to note that Tunisia is not very strong in terms of democratic institutions (political institutional quality) but has, in general, been politically stable. To some extent (in addition to the politics of co-optation and neutralization of major interest groups) this stability enhanced the perception of government credibility and commitment and facilitated coordination, which in turn helped put in place the necessary reforms with generally little confrontation.

Thus, Tunisia's path to development may provide useful lessons to replicate in other regions, as long as countries have macroeconomic and political stability, relatively good governance, and the political will to reduce inequality and enhance human capital.

\section{Concluding remarks}

The review and analysis of Tunisia's experience suggest that Tunisia's development strategy has relied primarily on diversifying its production, expanding the trade sector (both in terms of the size of its share and in terms of trade diversification), and human development - with a special emphasis on gender equality. 9 Overall, the country has managed to achieve a relatively harmonious marriage between economic (growth and income) and other important dimensions of social and human development. The success of Tunisia's 'early bird' strategy of focusing on diversification 10 was aided by several factors including the country's proximity to European markets and trade agreements with the EU,11 skilled labourforce, the quality and size of its female labourforce, and political and macroeconomic stability. In addition, this paper highlights the limits of Tunisia's development strategy in view of some challenges that the country currently faces, especially high unemployment rates, and outlines major lessons for other countries.

According to Bechri and Naccache (2003), 'the Tunisian experience proved also how crucial social modernization could be in isolating traditional groups and in rallying the support of women, trade unions and the liberal fringes of the population, as well as in improving the standard of living'. Thus, in this paper we also discuss the role of interest groups and political economy in shaping development policy in Tunisia.

9 See Baliamoune-Lutz (2007) for a study of the linkages between trade, female labourforce and gender inequality in Africa.

10 Tunisia also has an important tourism sector. Poirier and Wright (1993) point out that 'resort tourism has been perceived by policymakers as one of the best ways to improve the country's infrastructure while simultaneously becoming since 1974 the second largest earner of foreign exchange'. In 2006, Tunisia was one of the top African countries (ranked fourth) in tourism receipts which totaled US\$1.9 billion (UNECA 2007).

11 In 1996, the EU began funding a technological upgrading programme (Programme de Mise à Niveau) of Tunisian firms as part of its agreement of cooperation with the country. It is worth noting that in a recent study, Ben Hammouda, Chemingui and Bchir (2007) find that the Euro-Med agreement did not have a significant impact on the structure of Tunisia's imports of manufactures. 


\section{References}

Addison, T., and M. Baliamoune-Lutz (2006). 'Economic Reform when Institutional Quality is Weak: The Case of the Maghreb'. Journal of Policy Modeling, 28 (9): 1029-43.

Baliamoune-Lutz, M. (2006). 'Poverty and Inequalities in the Maghreb'. In C. H. Papatheodorou and M. Petmesidou (eds), Poverty and Social Deprivation in the Mediterranean Area. London: Zed Books.

Baliamoune-Lutz, M. (2007). 'Globalization and Gender Inequality: Is Africa Different?'. Journal of African Economies, 16 (2): 301-48.

Baliamoune-Lutz, M. (2008). 'Time Series Behaviour of Trade, Human Development and Income in Tunisia'. Jacksonville, FL: University of North Florida. Mimeo.

Bechri, M., and S. Naccache (2003). 'The Political Economy of Development Policy in Tunisia'. GRP/ERF.

Ben Hammouda, H., S. N. Karingi, A. E. Njuguna, and M. Sadni-Jallab (2006). 'Diversification: Towards a New Paradigm for Africa'. ATPC Work in Progress 35. Addis Ababa: UNECA-African Trade Policy Centre. Available at: www.mpra.ub.uni-muenchen.de/13359/1/MPRA_paper_13359.pdf .

Ben Hammouda, H., M. A. Chemingui, and M. H. Bchir (2007). 'Ten Years after Implementing the Barcelona Process in Tunisia: What We Can Learn from the Tunisian Experience'. ATPC Work in Progress 60. Addis Ababa: UNECA-African Trade Policy Centre.

Chamari, A. (1991). La femme et la Loi en Tunisie. Casablanca: Editions Le Femec.

Cook, W. D., M. Hababou, and L. Liang (2005). 'Financial Liberalization and Efficiency in Tunisian Banking Industry: Dea Test'. International Journal of Information Technology and Decision Making, 4 (3): 455-76.

Dollar, D. and A. Kraay (2003). 'Institutions, Trade and Growth'. Journal of Monetary Economics, 50 (1): 133-62.

Fargues, P. (1989). 'The Decline of Arab Fertility'. Population: An English Selection, 44 (1): 147-75.

Feng, Y., J. Kugler, and P. Zak (2000). 'The Politics of Fertility and Economic Development'. International Studies Quarterly, (44) 4: 667-93.

Fosu, A. K. (2002). 'The Global Setting and African Economic Growth'. Journal of African Economies, 10 (3): 282-310.

Fosu, A. K. (2003). 'Political Instability and Export Performance in Sub-Saharan Africa'. Journal of Development Studies, 39 (4): 68-82.

Ghali, S., and P. Mohnen (2004). 'The Tunisian Path to Development: 1961-2001'. Paper presented at the Conference on Scaling Up Poverty Reduction: A Global Learning Process and Conference, 25-27 May, Shanghai.

Jbili, A., K. Enders, and V. Treichel (1997). 'Financial Sector Reforms in Algeria, Morocco, and Tunisia: A Preliminary Assessment'. IMF Working Paper WP/97/81. Washington, DC: International Monetary Fund. 
King, S. J. (1999). 'Structural Adjustment and Rural Poverty in Tunisia'. Middle East Report, 210: 41-3.

Lapham, R. J. (1970). 'Family Planning and Fertility in Tunisia'. Demography, 7 (2): 241-53.

Pfeifer, K. (1999). 'How Tunisia, Morocco, Jordan and Even Egypt Became IMF "Success Stories" in the 1990s'. Middle East Report, 210: 23-7.

Poirier, R. A., and S. Wright (1993). 'The Political Economy of Tourism in Tunisia'. The Journal of Modern African Studies, 31 (1): 149-62.

Povey, W. G., and G. F. Brown (1968). 'Tunisia's Experience in Family Planning'. Demography, 5 (2): 620-6.

Ravallion, M., and M. Lokshin (2004). 'Gainers and Losers from Trade Reform in Morocco’. WB Policy Research Working Paper 3368. Washington, DC: World Bank.

UNCTAD (United Nations Conference on Trade and Development) (2004). Handbook of Statistics. Geneva: UNCTAD.

UNDP (2006). Human Development Report 2006: Beyond Scarcity: Power, Poverty and the Global Water Crisis. New York: UNDP.

UNECA (United Nations Economic Commission for Africa) (2004). Economic Report on Africa: Unlocking Africa's Trade Potential. Addis Ababa: UNECA.

UNECA (2007). Economic Report on Africa: Accelerating Africa's Development through Diversification. Addis Ababa: UNECA.

World Bank (2004). 'Tunisia: Development Policy Review - Making Deeper Trade Integration Work for Growth and Jobs'. Economic Report No. 29847-TN. Washington, DC: World Bank.

World Bank (2006). World Development Indicators, online. Washington, DC: World Bank. 
Appendix A

Table A1

GDP composition in selected countries (1970 and 2000)

\begin{tabular}{|c|c|c|c|c|c|c|}
\hline & \multicolumn{3}{|l|}{ GDP per capita, PPP } & \multicolumn{3}{|c|}{$\%$ share of: } \\
\hline & international \$) & (\%) & share (\%) & Manufacturing & Services & Agriculture \\
\hline & & & 1980 & & & \\
\hline Algeria & $5,089.70$ & 0.79 & 57.65 & 10.55 & 33.84 & 8.51 \\
\hline Argentina & $10,774.00$ & 4.15 & 41.22 & 29.48 & 52.43 & 6.35 \\
\hline Botswana & $2,652.70$ & 11.99 & 43.89 & 4.40 & 43.41 & 12.70 \\
\hline Brazil & $6,258.60$ & 9.11 & 43.83 & 33.49 & 45.16 & 11.01 \\
\hline Chile & $4,253.60$ & 8.15 & 37.44 & 21.52 & 55.30 & 7.25 \\
\hline Egypt & $2,108.50$ & 10.01 & 36.78 & 12.25 & 44.96 & 18.26 \\
\hline Ireland & $9,356.10$ & 3.08 & 35.94 & na & 52.27 & 11.79 \\
\hline Korea, Rep. & $4,197.50$ & -2.09 & 39.89 & 28.16 & 45.27 & 14.84 \\
\hline Malaysia & $3,730.30$ & 7.44 & 41.04 & 21.55 & 36.35 & 22.61 \\
\hline Mauritius & $3,764.00$ & na & 26.32 & 15.71 & 57.22 & 16.47 \\
\hline Morocco & $2,588.60$ & 3.64 & 30.94 & 16.83 & 50.63 & 18.43 \\
\hline South Africa & $10,415.00$ & 9.19 & 48.21 & 21.56 & 45.61 & 6.18 \\
\hline Thailand & $2,290.50$ & 5.17 & 28.68 & 21.51 & 48.08 & 23.24 \\
\hline Tunisia & $3,763.50$ & 7.42 & 31.11 & 11.79 & 54.76 & 14.13 \\
\hline \multirow[t]{2}{*}{ Turkey } & $3,656.70$ & -2.45 & 22.17 & 14.32 & 51.42 & 26.41 \\
\hline & & & 2000 & & & \\
\hline Algeria & $4,979.30$ & 2.40 & 59.74 & 7.75 & 31.49 & 8.77 \\
\hline Argentina & $11,131.00$ & -0.79 & 27.61 & 17.52 & 67.42 & 4.97 \\
\hline Botswana & $6,910.70$ & 7.55 & 46.24 & 4.72 & 51.16 & 2.60 \\
\hline Brazil & $6,780.70$ & 4.40 & 27.88 & 17.12 & 64.89 & 7.22 \\
\hline Chile & $8,411.80$ & 4.40 & 34.66 & 16.34 & 56.81 & 8.54 \\
\hline Egypt & $3,253.40$ & 5.11 & 33.06 & 19.35 & 50.24 & 16.70 \\
\hline Ireland & $27,612.00$ & 9.95 & 42.72 & 33.44 & 53.51 & 3.77 \\
\hline Korea, Rep. & $13,958.00$ & 9.33 & 42.39 & 31.28 & 52.92 & 4.70 \\
\hline Malaysia & $8,216.80$ & 8.50 & 50.82 & 32.66 & 40.54 & 8.65 \\
\hline Mauritius & $8,857.70$ & 4.00 & 31.60 & 23.98 & 62.54 & 5.86 \\
\hline Morocco & $3,195.30$ & 0.96 & 31.93 & 17.57 & 54.24 & 13.83 \\
\hline South Africa & $8,667.10$ & 3.50 & 31.14 & 18.58 & 65.64 & 3.22 \\
\hline Thailand & $5,846.10$ & 4.76 & 41.97 & 33.58 & 49.01 & 9.02 \\
\hline Tunisia & $5,754.20$ & 4.67 & 28.56 & 18.17 & 59.08 & 12.36 \\
\hline Turkey & $5,730.50$ & 7.36 & 25.29 & 15.65 & 59.35 & 15.36 \\
\hline
\end{tabular}

Source: World Bank (2006). 
Table A2

Diversification regimes* and TFP contribution to growth

\begin{tabular}{|c|c|c|c|c|}
\hline Countries & Growth in GDP & $\begin{array}{c}\text { Contribution } \\
\text { of labour }\end{array}$ & $\begin{array}{c}\text { Contribution } \\
\text { of capital }\end{array}$ & $\begin{array}{l}\text { Contribution } \\
\text { of TFP }\end{array}$ \\
\hline & \multicolumn{4}{|c|}{ Regime 2: Early diversification but no major breakthrough } \\
\hline \multicolumn{5}{|l|}{ Kenya } \\
\hline $1981-85$ & 2.53 & 2.31 & 0.86 & -0.64 \\
\hline $1986-90$ & 5.64 & 2.1 & 1.07 & 2.47 \\
\hline $1991-95$ & 1.61 & 2.14 & 0.86 & -1.39 \\
\hline $1996-2000$ & 1.79 & 1.9 & 1.01 & -1.11 \\
\hline \multicolumn{5}{|l|}{ Senegal } \\
\hline $1981-85$ & 3.23 & 1.56 & -0.01 & 1.68 \\
\hline $1986-90$ & 3.22 & 1.56 & 0.28 & 1.37 \\
\hline 1991-95 & 1.53 & 1.55 & 0.71 & -0.74 \\
\hline $1996-2000$ & 5.3 & 1.5 & 1.59 & 2.21 \\
\hline \multicolumn{5}{|l|}{ Zimbabwe } \\
\hline $1981-85$ & 4.36 & 2.55 & -0.07 & 1.88 \\
\hline $1986-90$ & 4.6 & 2.34 & 0.67 & 1.59 \\
\hline 1991-95 & 1.39 & 1.33 & 1.79 & -1.73 \\
\hline
\end{tabular}

Regime 3: Deepened diversification process

Mauritius

1981-85

1986-90

4.33

1.51

1.09

1.73

1991-95

7.39

1.31

2.66

3.42

5.13

1.08

3.05

0.99

South Africa

$\begin{array}{lllll}1981-85 & 0.91 & 1.74 & 1.42 & -2.25 \\ 1986-90 & 1.81 & 1.62 & 0.3 & -0.11 \\ 1991-95 & 0.89 & 1.44 & 0.18 & -0.73\end{array}$

Tunisia

1981-90

3.72

1.28

2.48

$-0.04$

1991-97

4.3

1.36

2.12

0.82

Note: * UNECA (2007) identifies five different diversification regimes and associates a regime to each country. Regimes 1, 2, 3, 4, and 5 refer, respectively, to little economic diversification; early diversification but no major breakthrough, deepened diversification process, backsliders in the diversification process, and conflict and post-conflict countries.

Source: UNECA (2007). 
Table A3

Trade and taxes on trade

\begin{tabular}{|c|c|c|c|c|c|}
\hline & & $\begin{array}{c}\text { Manufactures } \\
\text { export }\end{array}$ & $\begin{array}{l}\text { Ores \& metal } \\
\text { exports }\end{array}$ & \multirow{2}{*}{$\begin{array}{l}\text { Taxes on } \\
\text { international trade } \\
\text { (\% of current } \\
\text { revenue) }\end{array}$} & \multirow{2}{*}{$\begin{array}{l}\text { Import duties (\% } \\
\text { of tax revenue) }\end{array}$} \\
\hline & ( $\%$ of GDP) & \multicolumn{2}{|c|}{ (\% of exports) } & & \\
\hline & \multicolumn{4}{|c|}{1980} & \\
\hline Algeria & 64.68 & 0.32 & 0.46 & na & na \\
\hline Argentina & 11.55 & 23.15 & 2.17 & 0.00 & 0.00 \\
\hline Botswana & 119.48 & na & na & 39.11 & 53.12 \\
\hline Brazil & 20.36 & 37.21 & 9.41 & 7.14 & 9.09 \\
\hline Chile & 49.80 & 9.09 & 64.08 & 4.34 & 5.42 \\
\hline Egypt & 73.38 & 10.95 & 2.47 & 17.28 & 26.40 \\
\hline Ireland & 106.48 & 54.07 & 2.68 & 9.25 & 10.40 \\
\hline Korea, Rep. & 73.32 & 89.55 & 1.13 & 15.05 & 17.19 \\
\hline Malaysia & 110.96 & 18.75 & 10.19 & 33.03 & 16.52 \\
\hline Mauritius & 104.40 & 27.36 & 0.01 & 51.62 & 39.99 \\
\hline Morocco & 45.27 & 23.51 & 40.54 & 20.78 & 21.98 \\
\hline South Africa & 62.21 & 18.20 & 6.96 & 3.29 & 3.45 \\
\hline Thailand & 54.48 & 25.19 & 13.60 & 26.15 & 21.75 \\
\hline Tunisia & 85.84 & 35.72 & 3.62 & 24.66 & 31.14 \\
\hline \multirow[t]{2}{*}{ Turkey } & 17.09 & 26.88 & 7.03 & 5.96 & 6.80 \\
\hline & \multicolumn{4}{|c|}{2000} & \\
\hline Algeria & 63.77 & 2.31 & 0.25 & 18.47 & 9.25 \\
\hline Argentina & 22.41 & 32.25 & 3.30 & 5.22 & 5.17 \\
\hline Botswana & 98.76 & 89.56 & 6.97 & 15.47 & 37.72 * \\
\hline Brazil & 22.84 & 58.52 & 9.81 & na & $\mathrm{Na}$ \\
\hline Chile & 58.51 & 16.24 & 45.35 & 9.34 & $\mathrm{Na}$ \\
\hline Egypt & 39.18 & 38.43 & 3.87 & 10.37 & 17.06 * \\
\hline Ireland & 182.43 & 86.28 & 0.36 & 0.00 & 0.00 * \\
\hline Korea, Rep. & 86.53 & 90.75 & 1.26 & 6.54 & $7.45^{*}$ \\
\hline Malaysia & 229.28 & 80.43 & 1.04 & 12.29 & 12.72 *) \\
\hline Mauritius & 128.62 & 80.79 & 0.23 & 34.58 & 31.55 \\
\hline Morocco & 68.97 & 64.09 & 8.75 & 15.18 & 18.02 * \\
\hline South Africa & 54.44 & 54.31 & 10.85 & 4.12 & 3.04 \\
\hline Thailand & 124.91 & 75.56 & 1.30 & 16.45 & 12.20 \\
\hline Tunisia & 91.84 & 77.00 & 1.54 & 27.88 & 12.50 \\
\hline Turkey & 55.58 & 81.24 & 2.57 & 3.72 & 1.70 \\
\hline
\end{tabular}

Note: $\quad *=1995$.

Source: World Bank (2006). 